\title{
Teologická reflexe v supervizi pastorační práce
}

\section{Magdalena Ehrlichová}

V posledních letech se $\mathrm{v}$ naší zemi zřetelně rozvijí oblast pastorační péče ve zdravotnictví. Dohoda o duchovní péči a její dodatek z roku $2011^{1}$ umožnily zapojení nemocničních kaplanů do činnosti zdravotnických zařízení. ${ }^{2} \mathrm{~V}$ roce 2011 byla založena Asociace nemocničních kaplanů (dále jen ANK) a v roce 2012 Katolická asociace nemocničních kaplanů v České republice (dále jen KANK). Úkolem asociací je podpora činnosti a profesního vzdělávání nemocničních kaplanů a koordinace a propagace duchovní péče včetně spolupráce s důležitými subjekty v této oblasti.

Jako jedna z forem podpory pracovní činnosti kaplanů i dobrovolníků je ve stanovách obou asociací jmenována supervize. ANK zahrnuje do své náplně zajištění odborné péče o kaplany a dobrovolníky formou společných setkání a supervizí. ${ }^{3}$ KANK ve stanovách uvádí jako jeden ze svých cílů poskytování konzultační pomoci a supervize těm, kdo se věnují pastorační péči ve zdravotních a sociálních službách. ${ }^{4}$ Protože v současné době asociace věnují hodně sil rozvoji sítě nemocničních kaplanů a jejich vzdělávání, zůstává řešení otázky zajištění supervize v pozadí. $S$ informacemi o poslání a možnostech supervize, př́p. i se supervizí samotnou, se zatím nemocniční kaplani mohou setkat např. v rámci svých formačně-vzdělávacích setkání. Koncepční řešení způsobu poskytování supervize a požadavků na poskytovatele supervize $\mathrm{z}$ výše uvedeného důvodu však zatím zpracováno není. I nadále platí, že se supervize jako jedna z forem profesního doprovázení v naší zemi dosud profiluje především na poli sociální práce a psychoterapie a že v ostatních oborech, jako je např. zdravotnictví nebo pastorace, zůstává stále popelkou.

Nastíněná situace byla jedním z podnětů pro vznik tohoto př́spěvku, který chce ukázat možnosti supervize a její specifické rysy právě v oblasti pastorace, tzn. jakým způsobem lze reflektovat vlastní pastorační činnost. Text předkládá dva modely, které mohou pomoci v supervizi zvažovat teologicky významné podněty ovlivňující práci pastoračních pracovníků. První model, popsaný německým pastorálním teologem Isidorem Baumgartnerem, je založen na reflexi pastorační práce z pohledu čtyř základních funkcí církve. Vedle něj pak práce představuje druhý, nově koncipovaný model, který staví svou reflexi na struktuře pastoračního konceptu supervidovaného.

\footnotetext{
1 (C) Tiskové středisko ČBK, Dohoda o duchovní péči ve zdravotnictví mezi Českou biskupskou konferencí a Ekumenickou radou církví v České republice (on-line), dostupné na: http://tisk.cirkev.cz/res/data/008/001107.pdf?seek=1, citováno dne 15.10.2015.

2 (C) Asociace nemocničních kaplanů, Dodatek č. 1 k Dohodě o duchovní péči ve zdravotnictví mezi Českou biskupskou konferencí a Ekumenickou radou církví v České republice (on-line), dostupné na: http://www.nemocnicnikaplan.cz/rubrika /16-Dohoda-mezi-ERC-a-CBK/index.htm, citováno dne 15.10. 2015.

3 (C) Asociace nemocničních kaplanů, Stanovy (on-line), dostupné na: http://www.nemocnicnikaplan.cz/rubrika/3-Stanovy /index.htm, citováno dne 15. 10. 2015.

4 (C) Katolická asociace nemocničních kaplanů, Stanovy (on-line), dostupné na: http://kaplan-nemocnice.cz/wp-content /uploads/2014/03/Stanovy.pdf, citováno dne 15.10. 2015.
} 
Kromě českých zdrojů využívá tento př́spěvek podněty z německy a anglicky mluvícího prostředí, kde je supervize jako nástroj profesního růstu v oblasti pomáhajících profesí, včetně pastorační práce, často využívána. ${ }^{5}$

\section{Prostředí supervize}

Supervize je prostorem, ve kterém dochází k reflexi, interpretaci a hodnocení profesního jednání. Jedná se o proces, který skrze podporu personálních, sociálních a odborných kompetencí napomáhá k zajištění efektivity a humanity profesní praxe. ${ }^{6}$ Aktéry supervizního rozhovoru jsou supervizor a supervidovaný. Supervidovaným je pracovník (jednotlivec či skupina), který přichází s tématem ze svého pracovního prostředí, které chce ve společném rozhovoru reflektovat a pro které chce hledat možnosti řešení. Supervizor je na pozici toho, kdo supervizní proces ř́dí.?

\section{Pohled do historie}

Supervize ${ }^{8}$ jako jedna $\mathrm{z}$ forem doprovázení v praxi není nová disciplína. Vzory k tomu, co je označováno za supervizi, lze objevit již v situacích, kdy člověk poprvé začíná přemýšlet o svých sociálních vztazích a je nucen s druhými komunikovat o své práci. Vlastní kořeny supervize pak nalézáme na konci 19. století v oblasti zdravotnictví a sociální práce. Často je to $\mathrm{v}$ rámci zaučování nových pracovníků do profese, kdy nově přicházející pracovník dostává přiděleného zkušeného spolupracovníka, „supervizora“, který jej seznamuje s jeho prací, provází jej a př́padně i dohlíží na správnost postupů - zejména v počátcích jeho pracovního zařazení. V historii lze vedle tohoto stylu supervize sledovat ještě jiný model, a to rozhovory vikáře Samuela Barnetta se studenty, kteří se spolu s ním podíleli na charitativní činnosti v prostředí Londýna a kterým Barnett nabízel jako možnost podpory v jejich práci rozhovory „mezi čtyřma očima“.?

Důraz supervize se z ověrování správnosti postupu a oblasti vzdělávání v profesi přesunul v první polovině 20 . století vlivem psychoanalýzy na osobu klienta a řešení jeho situace. ${ }^{10}$ Později, částečně i pod vlivem společenského vývoje v oblasti rozpadu hierarchie a autority, ustupuje aspekt kontroly v supervizi téměř do pozadí a do centra pozornosti se dostává

\footnotetext{
5 Literární zdroje $\mathrm{k}$ tématu supervize v pastoraci z německého prostředí jsou převážně z 80. a 90. let 20. století, a to z toho důvodu, že v té době byla supervize v této oblasti poměrně novou disciplínou, a věnovala se jí proto značná pozornost. V současnosti se německá odborná literatura orientuje na téma supervize a koučinku jako podpory pracovníků napříč pomáhajícími profesemi.

6 Srov. Hilarion PETZOLD, Integrative Supervision, Meta-Consulting, Organisationsentwicklung. Ein Handbuch für Modelle und Methoden reflexiver Praxis, 2. vyd., Wiesbaden: VS Verlage für Sozialwissenschaften, 2007, s. 27.

7 Předpokladem pro činnost supervizora jsou znalosti a dovednosti ve vedení supervizního procesu. V naší zemi je nabízena řada supervizních výcviků s odlišnými nároky k jejich absolvování. Je to dáno tím, že u nás nejsou dosud jasně stanoveny jednotné kvalifikační požadavky. Kurzy mívají odlišnou hodinovou dotaci, cca 250-500 hodin, zahrnující jak získávání teoretických poznatků, tak rozvoj praktických dovedností. Frekventanti těchto výcviků jsou lidé z oblasti pomáhajících profesí - nejčastěji z oboru sociální práce, psychologie, lékařství, pedagogiky. Některé kurzy se cíleně zaměřují na vzdělávání v supervizi konkrétního oboru.

8 Použití pojmu „supervize“ se objevuje poprvé v polovině 16. století v právnických a církevních dokumentech ve smyslu vedení a kontroly. Pojem byl odvozen ze dvou latinských slov „super“, tj. nad, nej, a „visio“, tj. vidina, zjevení, pohled. V angličtině slovo „supervision“ označuje dohled, kontrolu, vedení. Srov. Nando BELARDI, Supervision: Grundlagen, Techniken, Perspektiven, München: C. H. Beck, 2005, s. 14-15.

9 Srov. Nando BELARDI, Supervision, s. 18-19.

10 Srov. Carlton E. MUNSON, Handbook of Clinical Social Work Supervision, Binghamton: Haworth Social Work Practice, 2002 , s. 56.
} 
podpora a rozvoj pracovníka. Sílí kreativita a autonomie a pracovní proces je výrazněji reflektován na pozadí vztahů, které se v něm objevují. ${ }^{11}$

\section{Supervizní rozhovor}

Základem supervize je rozhovor, odehrávající se $\mathrm{v}$ bezpečném prostředí a postavený na respektu a spoluodpovědnosti zúčastněných. $V$ průběhu supervizního rozhovoru jsou reflektovány vztahy mezi personálním a sociálním systémem, na jejichž základech pak mohou být měněny osobní, sociální a odborné kompetence a činnost supervidovaných. ${ }^{12}$ Jako jeden $\mathrm{z}$ pŕíkladů, které nám mohou přiblížit tento proces, bývá označován $\mathrm{z}$ antiky známý sokratovský dialog, ve kterém Sokrates jako učitel odmítal hrát se žákem hru otázkaodpověd' a reagoval na otázku žáka protiotázkou. Tento zpo̊sob studia vedl žáka $\mathrm{k}$ tomu, že se musel zamýšlet nad pozadím vlastních otázek, a tím i všeobecně nad životem. Takový postup je blízký i dnešním profesním reflexním metodám supervize. ${ }^{13}$

Pracovní vztah mezi supervizorem a supervidovaným vychází z rovnoměrného rozdělení odpovědnosti a spoluúčasti, $\mathrm{z}$ respektu $\mathrm{k}$ člověku jako jedinečnému bytí. Supervize proto ve své činnosti otevírá rámec, ve kterém nachází své místo každý obraz člověka. Teprve konkretizací jednání, postupů nebo intervenčních technik dochází k ujasňování norem a teoretických porozumění, které budou při supervizi reflektovány. Může se přitom stát, že jak supervizor, tak supervidovaní či organizace budou vycházet $\mathrm{z}$ rozdílných představ. ${ }^{14}$ Snahou supervize je, aby do svého náhledu zahrnula tělesnou, duševní i spirituální dimenzi člověka, včleněnou do sociálního prostř̌edí, a současně využila aktuálních i dějinných zkušeností supervidovaného. Základem pro naplnění hlavního poslání supervize je předpoklad, že člověk je schopen se i přes možná omezení rozvíjet.

\section{Cíle supervize}

Hlavní cílové oblasti, ke kterým supervize $\mathrm{v}$ pomáhajících profesích směřuje, jsou dle Christine Böckelmann následující: V oblasti zachování a zvyšování profesních kompetencí jde především o reflexi vlastní práce a rozšíření odborných poznatků $\mathrm{v}$ práci s cílovou skupinou. Jako další tematickou oblast označuje autorka téma vztahů ke zvolené cílové skupině, do které řadí např. analýzu své role ve vztahu ke klientům, osvětlení vztahu s klienty, vyrovnání se s očekáváními a požadavky klientů či hledání hranice v emocionálním odstupu vưči klientům. Do supervize zahrnujeme i téma včlenění pracovníka do prostředí organizace, to znamená porozumění a vyrovnání se s požadavky a cíli zaměstnavatele a institucí, se kterými spolupracuje, otázku loajality, možnosti spolupráce s kolegy. Jako čtvrtá oblast, které se supervize věnuje, je uvedena oblast řešení vlastní profesní identity, do které je zahrnuto posílení vlastní profesní role, vypořádání se s osobní stránkou povolání, vlastními představami, možnostmi a hranicemi vlastního jednání, řešení etických otázek profese. ${ }^{15}$

11 Srov. Nando BELARDI, Supervision, s. 49.

12 Srov. Hilarion PETZOLD, Integrative Supervision, s. 27.

13 Srov. Nando BELARDI, Supervision, s. 17.

14 Srov. Waldemar PALLASCH, Supervision: Neue Formen beruflicher Praxisbegleitung in pädagogischen Arbeitsfeldern, Weinheim:

Beltz Juventa, 1991, s. 53.

15 Srov. Christine BÖCKELMANN, Beratung - Supervision - Supervision im Schulfeld, Studien Verlag, 2002, s. 94. 


\section{Supervize v oblasti pastorační práce}

Pastorační činnost, ve které církev realizuje své poslání, se utváří na základě rozmanitých životních situací a z odpovědí církve na ně. Jde o dynamický proces, při kterém jsou permanentně sbírány a teologicky reflektovány a prohlubovány získané poznatky a zkušenosti. ${ }^{16}$

Specifikem supervize v pastorační práci je její teologické bohatství spolu s teologickým a duchovním porozuměním práci a pohledu na svět supervidovaného. Toto je dáno jednak tím, že sama duchovní rovina je součástí obsahu pastorační práce, a jednak tím, že se supervize zajímá o hodnotový žebrríček a náboženskou víru supervidovaných, ${ }^{17}$ to znamená, že se bude dotýkat jak pastorační, tak duchovní identity pracovníka. Úkolem supervize je, aby obě stránky rozlišovala a dovedla s nimi pracovat jak odděleně, tak v souvislostech, protože duchovní a pastorační identita bývá $\mathrm{v}$ práci pastoračního pracovníka propojena. ${ }^{18}$ V této chvíli je dobré připojit jednu poznámku. Podobně, jako je třeba rozlišovat např. mezi supervizí a poradenstvím nebo psychoterapií, je třeba dokázat odlišit supervizi pastorační práce od duchovního doprovázení. Supervize bude pracovat s osobní či duchovní stránkou supervidovaného vždy do té míry, nakolik se bude týkat jeho pracovní činnosti. Pokud bude supervidovaný pro sebe potřebovat ve větší míře pomoc terapeuta či duchovního vůdce, je úkolem supervizora, aby tuto věc rozpoznal, projednal ji se supervidovaným a odkázal jej na pomoc př́slušného odborníka.

Jakým způsobem lze tedy $\mathrm{v}$ supervizi reflektovat teologickou dimenzi pastorační práce a neopomenout zohlednit duchovní identitu pracovníka? V praxi je možné se setkat $s$ takovou formou supervize, která využívá všeobecně známých konceptů např. z oblasti supervize v sociální práci či psychoterapii a převádí je do pastorační oblasti. ${ }^{19} \mathrm{~V}$ rámci takové supervize není př́liš zvýrazněna otázka teologické reflexe - cíl práce se zaměřuje především na podporu a hledání jistoty supervidovaného ve své profesní roli bez možnosti hlubšího zpracování souvislostí se životem z víry jeho i supervidovaných. Cílem takové supervize je stávání se sama sebou. Vedle toho pak lze představit supervizi, která umožňuje ve své reflexi rozpoznat, využít a vyjádřit teologicky významné podněty, které následně mohou ovlivnit vlastní pastorační činnost supervidovaných. Supervizní práce tak není vyjádřena pouze v komunikaci člověka s člověkem, ale zahrnutím Boha do pracovního vztahu a snahou dívat se na projednávané skutečnosti i z jeho perspektivy. Cíl takové supervize charakterizuje Baumgartner jako stávání se subjektem v Božich očích. ${ }^{20}$

Tato druhá forma supervizní práce, která je podložená teologickou reflexí pastorační práce, klade vyšší nároky na samotného supervizora. Vedle potřebných znalostí a dovedností v oblasti supervize je pro něj důležitá jeho schopnost teologické reflexe i reflektovaná vlastní

16 Srov. Pavel AMBROS, Pastorální teologie I. Fundamentální pastorální teologie, Olomouc: Univerzita Palackého v Olomouci, 2002, s. 41.

17 Srov. Jane LEACH - Michael PATERSON, Pastoral Supervision. A Handbook, London: SCM Press, 2010, s. 10-11.

18 Srov. Keneth POHLY - Marilyn EVANS, The Multidisciplinary Nature of Pastoral Supervision: Integrating Supervision,

Counseling and Spiritual Direction, Journal of Supervision and Training in Ministry 18/1997, s. 57.

19 Srov. Isidor BAUMGARTNER, Theologische Dimensionen der Supervision von Mitarbeitern in Seelsorge und Caritas, Ueken: Aviva CQM-Script, Band 1-3, 1997, s. 8.

20 Srov. tamtéž, s. 9. 
zkušenost víry. Aby mohl supervizor účinně doprovázet pastorační pracovníky, je třeba, aby rozuměl podstatě křestanského života a etickým hodnotám, které jsou v životě a práci supervidovaných podstatné, aby znal poslání a prostředí církve, do které supervidovaní patří. Od takového nároku se pak odvijí i požadavky na prŕípravu a vzdělávání supervizorů $\mathrm{v}$ této oblasti. Protože $\mathrm{v}$ českém prostředí nejsou požadavky na profesi a vzdělávání supervizorů v pastorační oblasti dosud nijak specifikovány, práce na tomto místě představuje dva príklady ze zahraničí.

V Anglii byla $\mathrm{v}$ posledních letech ustavena Asociace supervizorů a vzdělavatelů v pastorační práci, u jejíhož vzniku stáli zástupci jednotlivých křestanských denominací v zemi a která systematicky rozvíjí obor supervize $\mathrm{v}$ pastorační práci. Supervizorem se zde stává ten, kdo již má praktické zkušenosti v oblasti pastorační práce. Od supervizora se zároveň očekává jeho duchovní a náboženská orientace a vyjádřený zájem o nauku víry i víru těch, kdo přicházejí na supervizi. ${ }^{21}$ Kurz supervize v pastorační práci zajištovaný touto asociací ve svém základu zahrnuje psychologické i teologické základy pastorační služby. ${ }^{22} \mathrm{Jako}$ další př́klad lze uvést Německo, kde jsou při většině biskupství pastoračním pracovníkům i katechetům $\mathrm{k}$ dispozici kontakty na vlastní poradce a supervizory či kouče. Některá z biskupství mají též vydána vlastní opatření o supervizi osob v pastoraci. Například opatření vydané berlínským arcibiskupstvím zahrnuje ve svém obsahu též základní požadavky na osobu supervizora, ke kterým náleží absolvování akreditovaného kurzu supervize, ${ }^{23}$ odborné a organizační kompetence, odpovědný postoj k poslání církve a schopnost skrze reflexi vlastní historie víry chápavě, kriticky a podnětně doprovázet pracovníky církve na pozadí jejich situace víry. ${ }^{24}$

\section{Zahrnutí teologické reflexe do supervize pastorační činnosti}

Účinná pastorační činnost závisí na schopnosti pastoračních pracovníků rozpoznat a využít teologicky významné pohledy způsobem, který objasní a bude utvářet jejich pastorační činnost. ${ }^{25}$ Následující text představuje dva konkrétní modely, jak lze pracovat v supervizním procesu $s$ teologickou dimenzí pastoračního poslání a jak povzbuzovat supervidované $\mathrm{k}$ teologické reflexi vlastního života a služby. První model ukazuje návrh Isidora Baumgartnera ${ }^{26}$ vycházet $\mathrm{v}$ supervizní reflexi ze základních funkcí církve. Druhý model, jehož koncepce zde bude nastíněna jako nová, vychází z poznatku Doris Nauer, že každý pastorační pracovník jedná, at již vědomě či nevědomě, dle určitého pastoračního konceptu. ${ }^{27}$ Právě jednotlivé body tohoto konceptu jsou v tomto př́spěvku využity jako základ osnovy, o kterou lze teologickou reflexi opř́t.

21 Srov. Jane LEACH - Michael PATERSON, Pastoral Supervision, s. 10.

22 Srov. tamtéž, s. 211-216.

23 V opatření je doporučeno absolvovat kurz národní asociace pro supervizi nebo národní společnosti pro pastorální psychologii, př́p. jejich ekvivalent.

24 (C) Erzbistum Berlin, Supervisionsordnung für das Pastorale Personal im Erzbistum Berlin (on-line), dostupné na:

http://www.erzbistumberlin.de/fileadmin/user_mount/PDF-Dateien/Amtsblaetter/Amtsblatt_201502_Anlage_Supervision.pdf,

aktualizace dne 1. 2. 2015, citováno dne 15.10. 2015.

25 Srov. Keneth POHLY - Marilyn EVANS, The Multidisciplinary Nature of Pastoral Supervision, s. 61.

26 Srov. Isidor BAUMGARTNER, Theologische Dimensionen, s. 10.

27 Srov. Doris NAUER, Seelsorgekonzepte im Widerstreit, Stuttgart: Kohlhammer, 2001, s. 20. 


\section{Teologická reflexe vycházející ze čtyř základních funkcí církve}

Baumgartner navrhuje přistoupit $\mathrm{k}$ teologickému zaměření supervize $\mathrm{v}$ pastoraci optikou čtyř základních funkcí církve: diakonie, liturgie, mystagogie a eklesiologie. Chápe je jako základní oblasti, kterése promítají do činnosti téměř každého pastoračního pracovníka, a jako takové by měly být podle něj v supervizi reflektovány. Supervize má tak u supervidovaných podněcovat jejich otevřenost pro život $z$ víry a jejich schopnost mystagogicko-evangelizačně interpretovat život. Supervize bude pro supervidované zároveň podporou v přijetí vlastní práce jako služby a umožní jim podívat se na sebe, druhé i svou práci v církevněspolečenském kontextu. Tuto stručně nastíněnou myšlenku Baumgartner rozvádí na konkrétním příkladu supervizní práce s kaplanem, který přichází s tématem vlastní nejistoty a obav při řešení následující pastorační situace: Na kaplana se obrátila s prosbou o pastorační návštěvu manželka muže, kterému není psychicky ani zdravotně dobře. Žena ví, že manžel je nevyléčitelně nemocný, ale s ohledem na jeho psychický stav má obavu $\mathrm{mu}$ ř́ci pravdu o jeho nemoci. Diakonická rovina supervizní práce směřovala $\mathrm{k}$ reflexi role kaplana v konkrétní situaci a $\mathrm{k}$ tomu, co on vidí jako důležité: Nechce být tím, kdo má udělat rozhodnutí za manželku, pokud jde o to, zda manželovi ř́ci o vážnosti jeho stavu, ale daleko více mu záleží na tom, jak může páru napomoci najít prostor, ve kterém spolu budou moci otevřeně hovořit a také se rozloučit, když to bude třeba. $K$ této reflexi patřil i náhled na dosavadní kaplanovy zkušenosti, jeho obavy a komunikační dovednosti, které s tématem loučení souvisí. To vše do té míry, do jaké to bylo potřeba pro práci s tímto párem. ${ }^{28}$

Na mystagogicko-evangelizační rovině bylo $\mathrm{v}$ rámci supervizního procesu zvažováno, jak kaplan pracoval s tématem víry a naděje - naděje přesahující i smrt. Supervize díky svému nastavení zároveň umožnila supervidovanému být v situaci, kdy je přijímán - i když jeho způsob řešení dané situace měl své rezervy, mohl si uvědomit, že ačkoli je nedokonalý, přesto je milován, mohl mluvit o naději a vykoupení ve svém životě. ${ }^{29}$

Na liturgickou rovinu bylo v supervizi odkázáno díky vyzdvižení role liturgických symbolů. Př́kladem může být pohled na eucharistii jako na místo setkání s Bohem, který daruje věčný život, zvláště v situaci, kdy je vlastní život ohrožen. Podobně je např. pastorační pracovník, který přichází k nemocnému, symbolem církevního společenství. ${ }^{30}$ Tímto se již pohled přesouvá na úlohu církve jako společenství, které i jednoduchým úkonem přinesení eucharistie nemocnému ukazuje, jak je v docela běžné události schopno zachytit obavy ze sociálního vyloučení a zároveň odkázat na samotnou Boží blízkost. ${ }^{31}$

\section{Teologická reflexe vycházející ze struktury pastoračního konceptu}

Tato práce přináší ještě jeden model, jak je možné koncipovat teologickou reflexi v supervizi $\mathrm{v}$ oblasti pastorace. Námětem $\mathrm{k}$ této úvaze je publikace německé teoložky Doris Nauer o práci s pastoračním konceptem. Autorka uvádí tezi, že každý pastorační pracovník, at již vědomě či nevědomě, v sobě nese koncept, podle kterého utváří svou praxi. Koncept se formuje z teologického vymezení konkrétní metody pastorace a s ním souvisejícího obrazu Boha a člověka. ${ }^{32}$

28 Srov. Isidor BAUMGARTNER, Theologische Dimensionen, s. 11-12.

29 Srov. tamtéž, s. 12-13.

30 Srov. tamtéž, s. 14.

31 Srov. tamtéž, s. 15.

32 Srov. Doris NAUER, Seelsorgekonzepte im Widerstreits, s. 20. 
Takový koncept nabízí pracovníkům prakticko-teologicky zdůvodněnou orientaci $\mathrm{v}$ jejich porozumění pastoraci a zároveň propojuje cíle, metody a obsahy jejich činnosti ve všednodenní praxi. Pastorační koncept slouží pracovníkům jako opěrný rámec v jejich činnosti a institucím či adresátům jejich péče nabízí čitelný obraz o pracovníkově roli a kompetencích. ${ }^{33}$ Takto strukturovaný náhled, který pracovník na základě svých poznatků, zkušeností a praxe rozvíí, mu napomáhá v utváření jeho vlastní pastorační identity.

Nauer ve své knize předkládá přibližně tři desítky připravených konceptů. Není však cílem této práce podat jejich přehled, ale využít myšlenky práce s konceptem a základní strukturu jeho členění jako vzor našich úvah $\mathrm{k}$ tomu, jak lze pastorační činnost $\mathrm{v}$ rámci supervize reflektovat.

\section{Struktura konceptu}

Každý jednotlivý koncept vychází z konkrétní metody pastorační práce a je charakterizován teologickým základem, obsahy a cílem k němu př́ślušné pastorační činnosti. Teologický základ konceptu se odvíjí především od způsobu argumentace, která bývá nejčastěji biblicko-teologicky či dogmaticky ukotvena. $V$ rámci této oblasti je pastorační pracovník veden $\mathrm{k}$ tomu, aby sám uvažoval nad tím, jak chápe pastoraci a $\mathrm{v}$ čem vidí obsah své práce a cíl, ke kterému směřuje. Patří sem i úvaha nad tím, jaký obraz Boha k př́slušnému modelu náleží. Dalším z opěrných bodů konceptu je obraz člověka, který s daným typem pastorační práce souvisí. Lze zde najít rozdíly z toho důvodu, že teologický úhel pohledu na člověka bývá často propojen např. s filosofickými, psychologickými či sociologickými postuláty. ${ }^{34}$

Do pastoračního konceptu patří i role a kompetenční profil pracovníka. Kompetenční profil pracovníka se odvíjí od toho, zda je pastorace charakterizována výlučně teologicky, nebo ve vztahu k neteologickým disciplínám. $Z$ toho se pak vychází při zvažování, zda je pro pracovníka potřebná odborně teologická, duchovní, osobní či jiná odborná kompetence. Pastorační koncept $\mathrm{v}$ sobě dále zahrnuje vybrané metody práce, to znamená, jaké metody práce ve své každodenní praxi pracovníci využívají, jaké jsou jim blízké. V pastoračním konceptu má své místo dále charakteristika cílové skupiny. $\mathrm{V}$ rámci daného konceptu rozlišujeme, zda se jedná o individuální pastoraci či pastoraci specifických skupin, či jde o obecné vymezení adresátů pastorace (např. pro všechny křestany). Poslední součástí pastoračního konceptu je vymezení intra- a interdisciplinární spolupráce. K této části patř́ zvážení formy a možností spolupráce uvnitř či vně církve, instituce či prostř̌edí, kde je pastorační činnost vykonávána. ${ }^{35}$

Jak může být předložená struktura pastoračního konceptu užitečná v procesu supervize? Jednotlivé body tohoto konceptu umožňují náhled na pastorační práci v celé její šíri. Přri přijetí myšlenky, že každý pracovník pracuje $\mathrm{v}$ rámci určitého pastoračního konceptu, může supervize sloužit jako prostředek kultivace tohoto konceptu, jako nástroj vytváření vlastní pastorační identity. Práce s konceptem odkrývá odborné poznání a rozvijí specifické dovednosti, které pracovník využívá ve své práci. Umožňuje pracovníkovi rozumět sobě samému a tomu, „co, jak a proč“ dělám.

33 Srov. tamtéž, s. 13.

34 Srov. Alois KŘIŠŤAN, Pastorační koncept, in: Praktická teologie pro sociální pracovníky, ed. Michael MARTINEK, Praha: Jabok, 2008, s. 72-74.

35 Srov. tamtéž, s. 74-75. 


\section{Př́klad práce s pastoračním konceptem v supervizi}

Jako prŕklad využití práce $s$ konceptem $\mathrm{v}$ supervizi zde bude charakterizován koncept doprovázející pastorace a poté bude odkázáno na to, jakým způsobem může být užitečný pro supervizní reflexi.

\section{Pastorační koncept doprovázející pastorace}

Doprovázející pastoraci lze charakterizovat jako doprovázení lidí v krizové situaci jejich života, které je motivováno křestanskou vírou. ${ }^{36}$ Cílem této formy pastorace je pomoc životu a víř člověka skrze blízkost a podporu druhého. Je to metoda pastorační práce, která bývá často využívána v klinické pastorační praxi. ${ }^{37}$

Teologický základ doprovázející pastorace je biblicky doložen jednáním Boha, jenž věrně doprovází svůj lid. Ve Starém zákoně lze najít obraz Boha jako věrného průvodce izraelského lidu v průběhu jeho dějin. ${ }^{38}$ Nový zákon popisuje jednání Ježíše, které ukazuje, jak je Bůh lidem vjejich životních dějinách opravdu blízko. Př́klad Ježíše zároveň umožňuje normativně doložit tento způsob pastorace i ji obsahově popsat. ${ }^{39}$ Jako další argument ke zdůvodnění tohoto modelu je předložen obraz dobrého pastýře. Ježís jako dobrý pastýř nejen že je sám prŕkladem tohoto typu pastorace, ale zároveň ji i od svých věrných vyžaduje. ${ }^{40}$ Člověk je $\mathrm{v}$ tomto konceptu viděn jako Boží obraz, jako ten, kdo je Bohem stvořen, povolán a osobně milován. Jde zde o celistvý obraz člověka spočívající v jeho duševní, tělesné a duchovní jednotě. ${ }^{41}$

Ve své práci se pracovník setkává jak s věŕícími, tak i nevěřícími. V této formě pastorační činnosti je zdůrazněna především podpora člověka $\mathrm{v}$ jeho konkrétní a jedinečné situaci. ${ }^{42}$ I prosté spolubytí pastoračního pracovníka s nemocným či trpícím člověkem může být znamením vnitřního spojení Boha s člověkem a člověka s Bohem v utrpení, a to bez ohledu na hloubku víry trpícího člověka. ${ }^{43}$

Při tomto stylu pastorační práce je důležité, aby si pracovník uvědomoval, že pracuje s lidmi jako subjekty péče, že je tím, kdo doprovází, a ne tím, kdo léčí. Předpokladem pro jeho práci je otevřenost, prátelskost, schopnost navázat kontakt, zájem, důvěra, spolehlivost. Od pastoračního pracovníka se očekává, že bude člověkem duchovně zakořeněným, bude mít vzdělání v oblasti klinické pastorační péče a bude ochoten dále profesně růst.

\footnotetext{
36 Vírou se zde myslí základní lidská důvěra, která se dokáže odevzdat nepochopitelné, nepředvídatelné a nekontrolovatelné skutečnosti. Srov. Doris NAUER, Seelsorgekonzepte im Widerstreit, s. 102, 105.

37 Tento pastorační model vytvořili kliničtí pastorační pracovníci a teologové, aby rozvinuli teorii pro oblast každodenní činnosti v nemocnici. Ačkoliv je mezikonfesním produktem, má v katolickém prostředí značnou úlohu, protože hrál rozhodující roli v nahrazení předkoncilního modelu pečující pastorace. Srov. tamtéž, s. 100.

38 Srov. Rolf ZERFASS, Menschliche Seelsorge, Freiburg: Herder, 1985, s. 99.

39 Srov. tamtéž, s. 84.

40 Srov. Reinhold GESTRICH, Hirten füreinander sein. Seelsorge in der Gemeinde, Stuttgart: Quell-Verlag, 1995, s. 8-24.

41 Srov. tamtéž, s. 122.

42 Srov. Doris NAUER, Seelsorgekonzepte im Widerstreit, s. 109.

43 Michal OPATRNÝ, Impassibilis est Deus, sed non incompassibilis: Srovnání pohledů Jana Pavla II. a Benedikta XVI. na utrpení z pastorálního hlediska, Theologos 1/2011, s. 67.
} 


\section{Podněty k supervizní práci v rámci konceptu doprovázející pastorace}

Východiskem vlastní supervizní prácejsou vždy konkrétní podněty z praxe supervidovaných. Tematicky korespondují s cíli uvedenými $\mathrm{v}$ úvodu této práce. Jejich představením a postupným zpracováním se supervidovaní dostávají k hlubším otázkám týkajícím se hledání smyslu vlastní práce, odůvodnění zvolených postupů, reflexe hodnot a nacházení souvislostí.

S ohledem na vybranou pastorační metodu doprovázející pastorace lze v reflexi konkrétního způsobu a postupů práce narazit na otázky vztahující se $\mathrm{k}$ jisté bezmoci při tomto úkolu doprovázení, protože cílem tohoto způsobu pastorační práce je opravdu ,jenom“ být s druhým. ${ }^{44}$ Supervize ve svém procesu pak umožní reflektovat pocit, který máme, když přicházíme $\mathrm{k}$ nemocným $\mathrm{s}$ prázdnýma rukama, nejistotou a strachem, a pomůže nám v získávání postoje důvěry a otevřenosti.

V rámci takové supervize se lze učit, jak doprovázet nemocné s jejich pocity a přitom dávat pozor na své city, jak být autentický, solidární a zároveň si umět zachovat i odstup. Supervizní proces podepřený pohledem na tento pastorační koncept může být inspirací $\mathrm{k}$ hlubšímu provázání konkrétních supervizních témat do kontextu:

- jak pracovník sám chápe svou roli, zda dokáže být jak pastýřem, tak ovcí s vědomím, že jediným pastýřem nás všech je Kristus; ${ }^{45}$

- jakou roli v projednávané situaci hraje jeho víra a vlastní zkušenost ze setkání s Bohem a možností nechat se od Boha provázet;

- jakým způsobem ve zvolené situaci pracovník prezentuje druhým, at již explicitně či implicitně, blízkost Boha;

- jak pracovník vnímá člověka, kterému se věnuje: zda je pro něj tím, koho stvořil a povolal si Bůh; zda je pro něj tento člověk opravdu subjektem, a ne objektem péče;

- jak je vlastní pastorační činnost propojena s dalšími subjekty péče - jaké jsou v projednávané situaci možnosti a překážky vzájemné spolupráce $s$ pracovníky organizace, $s$ rodinou a blízkými nemocného, s vlastní farností či církví.

Na základě reflexe získaných zkušeností a poznatků si pracovník v supervizi ověřuje nastavení pastoračního konceptu vlastní práce a má možnost jej s ohledem k nově získaným poznatkům prohlubovat a upřesňovat. Práce se strukturou pastoračního konceptu v supervizi tak supervidovanému umožňuje namísto bezmyšlenkovitého a situačního jednání promyšleně utvářet svou pastorační identitu. Využití struktury pastoračního konceptu $\mathrm{v}$ supervizi může být také velice užitečné $\mathrm{v}$ období profesních začátků pastoračních pracovníků, kdy pracovníci hledají svůj vlastní styl práce a potřebují rámec, o který se mohou ve své praxi opírat. Pokud využijeme tento způsob práce v supervizní práci se skupinou, určitě bude neocenitelným př́nosem pro všechny zúčastněné setkání s odlišnými př́stupy a reflexemi druhých. 


\title{
Závěr
}

Tato studie představila některé ze specifických aspektů supervize pastorační práce vyplývající z potřeby teologického porozumění obsahu práce a pohledu na svět supervidovaných. V návaznosti na toto téma bylo v textu zvažováno, jakým způsobem lze v supervizi koncipovat teologickou reflexi pastorační činnosti. Jako první model byl ukázán Baumgartnerův návrh reflektovat $\mathrm{v}$ supervizním procesu pastorační práci optikou základních činností církve. Jako nový model vedení reflexe byla v této studii představena supervizní práce využívající struktury pastoračního konceptu, který umožňuje komplexní, teologicky podložený náhled na činnost pastoračního pracovníka. Do jaké míry lze využít tyto návrhy v praxi, zůstává především v kompetenci supervizora a ve schopnostech supervidovaného. Je to supervizor, kdo nese odpovědnost za strukturu supervizního rozhovoru a kdo tento proces s ohledem na možnosti a požadavky supervidovaného moderuje.

V některých zemích se supervize již stala nedílnou součástí profesního rozvoje kněží, katechetů a pastoračních pracovníků. Pracovníci se s ní setkávají jak v rámci své profesní př́pravy, tak při vlastním výkonu profese. $V$ našem prostředí se $\mathrm{v}$ oblasti pastorace se supervizí setkávají studenti teologických fakult v rámci své studijní praxe a dále je využívána především v organizacích propojujících pastorační a sociální práci (zařízení charity, hospice, nízkoprahová zařízení). Je na místě, že se se supervizí počítá i v náročné práci nemocničních kaplanů.

Tento př́spěvek nás může přivést i k otázkám: Pokud vnímáme supervizi v oblasti pastorační práce jako opodstatněnou, co můžeme udělat pro její rozvoj v našem prostředí? Jak můžeme napomoci tomu, aby supervize pastoračních pracovníků byla prostorem teologické reflexe? Co jako pastorační pracovník od supervize očekávám a co mohu získat? Jak mi může supervize napomoci najít sama sebe se svou vírou ve své profesi?

\section{Teologická reflexe v supervizi pastorační práce}

\begin{abstract}
Abstrakt
Článek představuje supervizi jako disciplínu, která může pastoračním pracovníkům pomoci při zvládání nároků jejich profese. Na základě charakteristiky supervize v oblasti pomáhajících profesí jsou v textu zvažována její důležitá specifika pro oblast pastorační práce. Předpokladem supervize v oblasti pastorace je její teologické a duchovní porozumění oblasti pastorační práce i světu pastoračního pracovníka. Článek předkládá návrhy, jakým způsobem Ize koncipovat teologickou reflexi v supervizi pastorační práce.
\end{abstract}

Klíčová slova: supervize, pastorace, teologická reflexe, pastorační koncept, pastorační pracovník 


\title{
Theological Reflection in Pastoral Supervision
}

\begin{abstract}
The paper presents supervision as a discipline that can help pastoral workers cope with the demands of their profession. Based on the characteristic of supervision in helping professions the text considers its important specificities for the field of pastoral work. A prerequisite of pastoral supervision is its theological and spiritual understanding of the field of pastoral work as well as the world of the pastoral worker. This paper presents suggestions on how to conceive theological reflection in pastoral supervision.
\end{abstract}

Keywords: supervision, pastoral care, theological reflection, pastoral concept, pastoral worker

\section{Kontakt na autora}

\section{Mgr. Magdalena Ehrlichová}

Jihočeská univerzita $v$ Českých Budějovicích

Teologická fakulta, Oddělení praxe

Kněžská 8, 37001 České Budějovice

ehrlich@tf.jcu.cz 